\title{
The Open Innovation of Café Chain Stores and Its Influence on the Business Model
}

\author{
Wan.JuChiang ${ }^{1}$, James K.C.Chen ${ }^{2}$ and Tain.FungWu ${ }^{2}$ \\ ${ }^{1}$ Department of Management, Asia University, No.6 RenAi Road, Wufeng, Taichung 41354, Taiwan ROC \\ ${ }^{2}$ Department of Management, Asia University, No.500 Liufeng Road, Wufeng, Taichung 41354, Taiwan ROC \\ m24926930@yahoo.com.tw, \{kcchen \& thomaswu $\} @$ asia.edu.tw
}

\begin{abstract}
The global economy development is changing radically. All of the companies are facing a challenging environment which changes every moment. Therefore, all of the companies are need a business model which can solve all the coming problems and run their businesses smoothly. Open innovation had caughtots of researchers' attention in the United States and Europe, but just makes its debut in Taiwan. Companies in Taiwan rarely focused on customer satisfaction in the past. They hadn't paid attention to the companies with open innovation, which is the theme of this research. The research chooses three well-known companies in Taiwan for the survey, including $85^{\circ} \mathrm{C}$ Café Bakery, Starbucks, and E Coffee Company. The study used depth study to meet the managers of the direct distributors and franchise stores, and recorded the whole conversation in order to use the information to analyze the practicability of open innovation theory. The result shows that coffee chain stores can reduce the waste of resources by using open innovation operation model; furthermore, the model can increase the companies' revenue, and the partners of the companies can share with one another their experiences.
\end{abstract}

Index Terms - open innovation, service quality, customer satisfaction, business model

\section{Introduction}

The concept of open innovation has been growing rapidly over the recent years and has become a mainstream in industry management practices. The idea was first brought forward in 2003by Chesbrough who suggested that innovation in an enterprise should be brought about in two ways. One way is from outside to the inside meaning an enterprise can and should introduce exterior ideas and technologies in combination with interior ones to accelerate newer technology developments [1].

The other way is from inside to the outside. An enterprise can harvest more from the know-how and technology and researches they get through cooperationwith other corporations. Moreover, an innovation can not only be utilized by the enterprise itself, but also by the others through startups, or technology franchising, to maximize the value of the enterprise. Lots of researches had been done referring the operation of the café chains. A majority of the studies had focused on marketing-strategies. Little had been done over the impact of open innovation on the service industry. The business operators need to adopt open innovation to enhance their competitiveness.

This study will discuss about the open innovation of the café chain stores and its influence on the business model.

\section{Literature Review}

\section{A. Open Innovation}

Henry Chesbrough (University of California, Berkeley) was the first person to promote open innovation. He mentioned that innovation should not be limited to a project, in a research level or on the implementation stage. Enterprises should integrate the exterior know-how and newly creative ideas with their own in-house researches to push more technology development and create higher value [1].In a case study, Pan, How-Wei (2011), found that the adoption of open innovation did affect a small and medium enterprise called Young Optics on technology level, leading to eight effective results, upgrading its capacity and employees' performance by adopting the paradigm[2].

$\mathrm{Ku}$, Chia-Yu (2013) studied the application of the theory on the Smartphone market. He took the case of Qualcomm in China as an example, for its rapid penetration into the dual-SIM-card Smartphone market. Qualcomm's achievement was the result of applying group research, instead of independent study, to develop their well-accepted phones within a short period. The reward was shared from a partner who substantiates an important role of open innovation [3].

\section{B. Open Innovation and Closed Innovation}

The concept of innovation was first introduced by the famous economist Schumpeter (1934), who believed it could lead an enterprise to further utilize the existing resources and to renew and develop their technology. In respect to workflow, innovation is a procedure that can turn an idea out to be a product or make an existing product profitable. Innovation not only takes place inside are search lab but can happen at any point in a business. For this reason, innovation should include enterprise, procedure and business innovation [4].

Chesbrough (2003) gave a detailed description of innovation. The book compares the efficiency generated from open innovation and closed innovation and points out that open innovation can lead to either higher profitability or lower cost. Higher profitability derives from technology trading, new businesses, and related authorization[1].

When open innovation is compared to closed innovation, the obvious differences include opening new enterprise boundaries, new operation mindset, and a new business model. The importance of open innovation is shown in Table 1. 
Table1 Open Innovation Vs. Closed Innovation

\begin{tabular}{|c|l|l|l|l|}
\hline Innovation Type & \multicolumn{1}{|c|}{ Human Talent } & \multicolumn{1}{c|}{ Research } & \multicolumn{1}{c|}{ Business Strategy } & \multicolumn{1}{c|}{ Intellectual Rights } \\
\hline Closed & $\begin{array}{l}\text { Hire the most talented staff in the } \\
\text { field. Every researcher becomes } \\
\text { an outstanding inventor. }\end{array}$ & $\begin{array}{l}\text { Enterprise makes its } \\
\text { own innovation for new } \\
\text { products to get reward. }\end{array}$ & $\begin{array}{l}\text { The one first transforms } \\
\text { the technology into a new } \\
\text { product is the winner. }\end{array}$ & $\begin{array}{l}\text { The Enterprise has theownership of the } \\
\text { rights. No competitor can profit from the } \\
\text { new technology. }\end{array}$ \\
\hline Open & $\begin{array}{l}\text { Cooperate with both internal and } \\
\text { external talent. Everyone in the } \\
\text { enterprise can be innovative and } \\
\text { has a business mindset. }\end{array}$ & $\begin{array}{l}\text { Internal research should } \\
\text { reach partial value; } \\
\text { external research creates } \\
\text { a mass fortune. }\end{array}$ & $\begin{array}{l}\text { Creates a better business } \\
\text { model than first-to-enter } \\
\text { strategy. }\end{array}$ & $\begin{array}{l}\text { An enterprise should trade its intellectual } \\
\text { rights for profit. Also a business can } \\
\text { change its business model or acquire } \\
\text { intellectual rights from others. }\end{array}$ \\
\hline
\end{tabular}

Data Source:[5]

\section{Procedures of Closed and Open Innovation}

Closed innovation starts from the basis of science and technology, followed bya series of steps, and creates a product market as shown in Fig.1. The procedure is called "closed" because it's only going on a single way-one way in and one way out.

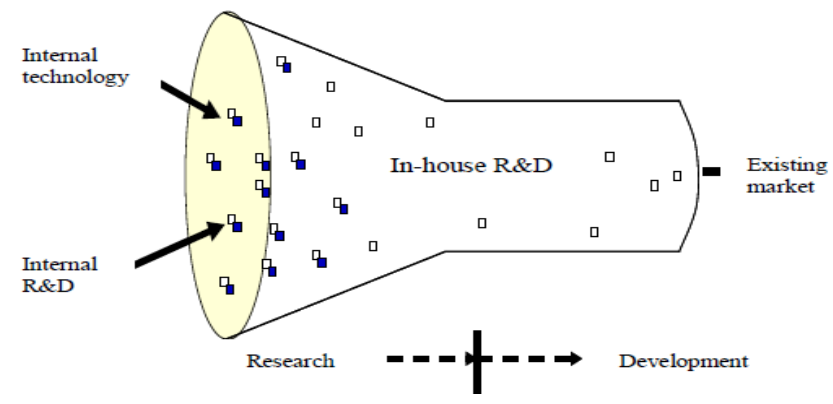

Fig. 1 Closed Innovation Paradigm

Open Innovation procedure, as shown in Fig. 2, comes from a new technology or resource, internally or externally, which can enter at any phase when needed. The results are also multi-faceted. For example: transferring self-developed technology to others through licensing; establishing a new subsidiary for the product; selling it on the existing market through current marketing paths. "Open" here means diverse ideas or technologies flowing into the procedure, as well as flowing out to the market.

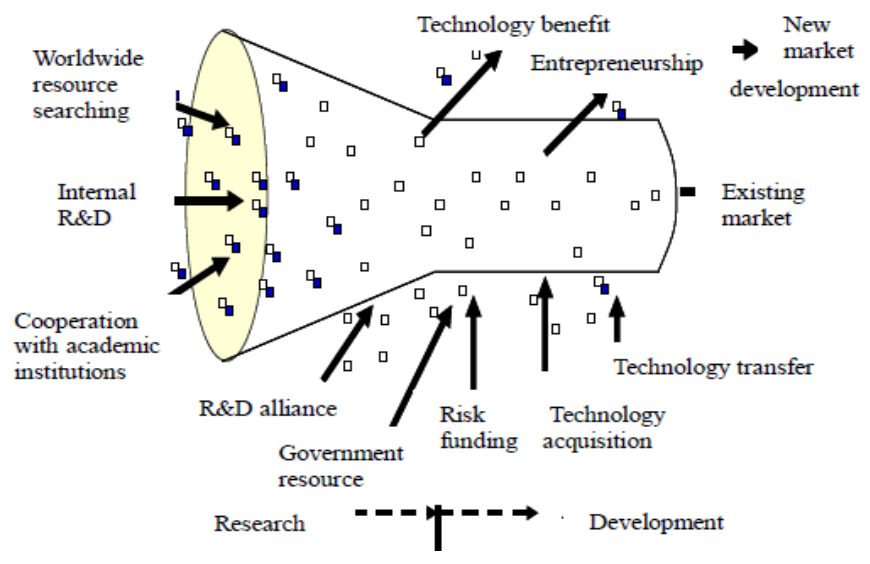

Fig. 2 Open Innovation Paradigm

Data Source: [1]

\section{Case Companies}

\section{A. Starbucks Coffee [6]}

Starbucks Coffee International, Seattle, Washington, was founded in 1971 and is the largest Café chain stores in the US. The President Starbucks Coffee Corp is a joint venture in Taiwan in 1988 formed by Starbucks Coffee International, Uni-President and the Seven Eleven Convenient Stores under the President Group. The café offers mid-to-high priced coffee drinks or pastries but do not provide meals. The CEO of Starbucks International, Howard Schulz, uses the idea of "customer first" to run the business. He insists on using only the highest-quality roasted beans to offer the best coffee under a cozy store environment.

\section{B. $85^{\circ} \mathrm{C}$ Café [7]}

$85^{\circ} \mathrm{C}$ Cafésells various cakes and coffee drinks. The coffeehouse was founded by a Taiwanese chain business guru, Wu, Cheng-Xue in 2004 in Yunghe City, with the aim to provide five-star foods and beverages through out Taiwan at afford able prices. They take that $85^{\circ} \mathrm{C}$ is the idealistic temperature to taste coffee. Since its establishment, $85^{\circ} \mathrm{C}$ has successfully penetrated into the new customer clusters at a lowprice, under the slogan of "the luxurious enjoyment at an affordable price." $85^{\circ}$ Chas more than 440 stores now, of which $90 \%$ are franchised. The Brand is by far the most successful and largest chain coffeehouses in the local coffee \& cake market.

\section{Ecoffee[8]}

The chain store oriented from a small café whose owners were experienced coffee drinkers and they always requested the finest coffee. They started the café with their affection for good coffee taste and the ambition to promote high-quality coffee and to bridge the gap between the less-affordable imported coffee and the lower quality but cheaper domestic products. Ecoffee, implying "the best coffee shop in the electronic age", kicked off in 2002 and promoted its service concept by asking "who says a NT\$35 coffee can’t be good?" The café brews per order with scrupulously selected beans, to make sure its customers enjoy fine coffee at a cheaper price. The chain store quickly gained popularity as a result of wide-spread locations in many busy streets and alleys and created a trend for lower prices in the coffee drinking market. E Coffee is now one of the leading coffeehouses and aims to become another "Starbucks" in the Chinese-spoken areas in the world. 


\section{Research Approach}

\section{A. Case Study and Data Collection}

Our case study comprises of three well-known café stores, Starbucks, $85^{\circ} \mathrm{C}$ Café, and E Coffee. We met three senior managers, eitherastore manager or senior staff person, from each subject, for a total of nine interviews. We apply $\mathrm{Q} / \mathrm{A}$ technique to obtain information of the interviewees referring to the concept of open innovation and its implementation.

\section{B. Research Procedures}

Our initial study covered the background, current operation status, core business ideas, and results of open innovation in the three companies. We then introduced our research approach, gave in-depth descriptions of the interviews and made summaries to extract the key points. Finally, in our conclusions, weare able toderive recommendations that can be helpful to thedaily operations of businesses.

\section{Case Study}

A. Subject Company and the Interviews.

Before we conducted the interviews, we sourced as much information as we could about the companies, including all available material and publications, sub-level information resources such as company websites, related news, articles and books to ensure we had a rough understanding of each company before our meetings. We selected interviewees from amongst the senior managers in director franchised stores. We designed our questions about open innovation to make sure that the interviewees can freely express their ideas, experiences and details of business with respect to the theme. All meetings were recorded and the information were then re-composed and analyzed by the researchers.

Key questions asked during the interviews including:

1) What partner strategies are applied for open innovation?

2) What product strategies are applied for company innovation?

3) How is customer service efficiency applied with the introduction of open innovation.

\section{B. Starbucks Interview Summary}

Starbucks currently uses four different partnership modes: joint venture, licensing agreement, authorized operation, and cross-sector alliance. In a joint venture, the partner and Starbucks own 50\% shares for each, which is the most popular operation mode in Taiwan, Japan, and Korea. In a licensing agreement, Starbucks only takes a smaller portion of shares, which is popular in Taiwan, Hawaii, and Shanghai (before the capital increases). For the authorization mode, Starbucks doesn't participate in the operation of the stores but authorizes to the stores. The mode is popular in the Philippines, Singapore, Malaysia, and China,...etc. The Cross-sector alliance is a rather more aggressive strategy designed by Starbucks, with the café stores located in school campuses, business buildings, hospitals, or other institutions. Innovated products are not limited to coffee drinks; they include selling coffee beans, coffee making equipment, books, and pastries.
The company believes that the customer return ratio depends not only on good coffee to drink, but also on good services and the coffee-related information which the customers receive from the staff. Starbucks' costis twice as expensive as that of the competitors per cup. The target customer has been selected through pricing because Starbucks the coffee giant believes that profit can be maintained at a certain level after the target customers be differentiated.

\section{C. $85^{\circ} \mathrm{C}$ CaféInterview Summary}

$85^{\circ} \mathrm{CCafécurrently}$ uses three different partnership modes including cross-sector alliance, licensing agreement, and internal startups. Through open innovation, and alliances with other industries, the coffeehouse has recently builtan agency in Australia and is to initiate a direct operation therein the near future. It also has planned to work in China with Ting Shin Group. On the joint-venture mode, the company directly emerges in the chain-stores' operations. Taiwan is a rather mature market for the mode, the number of new stores has been rapidly expanding under the authorization of the franchise. During our interview, 80\% $90 \%$ of the $85^{\circ}$ CCafé stores were franchised. Every manager is a shareholder and owner. Not only does the chef get a part of the share, but every employee receives his monthly bonus aside from their salary based on personal performances. The policy has boosted the morale and successfully encouraged the employees.

$85^{\circ} \mathrm{CCafé} \mathrm{has} \mathrm{continuously} \mathrm{introduced} \mathrm{new} \mathrm{cakes} \mathrm{to} \mathrm{give}$ customers more selection. Furthermore, the product lines have also been expanding in category and items such as a Japanese food called dorayaki, other new flavored drinks, and seasonal products to strengthen sales, and customer brand loyalty. $85^{\circ} \mathrm{CCafémaintains} \mathrm{a} \mathrm{neat} \mathrm{store} \mathrm{decoration} \mathrm{by} \mathrm{setting} \mathrm{some}$ tables and chairs to form a venue for friends to join gather. Many of the stores are located at traffic junction areas and corners in $2^{\text {nd }}$ and $3^{\text {rd }}$ tier cities to differentiate from the competitors in terms of market positioning.

\section{E Coffee Interview Summary}

E Coffee currently uses three different partnership modes including joint venture, cross-sector alliances, and authorized operation. Through alliance, E Coffee and its business partners hold $50 \%$ of the new ventureineach store; while across-sector alliance calls for different shares holdings through negotiation. A good example of its cross-sector alliance is the alliance with I-Shou University, located in Da-shu District, Kaohsiung City. Its concept behind the alliance is to fill the campus with the smell of coffee as a promotion to increase sales.

The coffeehouse has completed its first authorized overseas agreement with One Two Holdings of Singapore to enter another Chinese-spoken market. Withits successful experience, E Coffee also opened its first directly-operated flagship store in Xiamen and introduced a new business concept that combines a coffeehouse and a bakery. The bakery has been well accepted for its quality. E Coffee positioned its brand name in 2011 by extending its business scope to the operation of much wider and more roomy cafés with a cozy ambience. The change has brought lots of profit. The great transition since its establishment 11 years ago indicates the 
coffee chain store is continuing to make efforts to provide more professional services and delicate food.

\section{E. Discussion}

Our study has shown that both low-price chain coffeehouses and compound coffee chain stores have their own ways of introducing new ideas and products under an open-innovation mode. The three stores ally with other sectors to create greater additional value. With more and more coffee chain stores entering the market, the existing operators are striving to offer distinctive features through a unique business model derived from open innovation to attract different customer groups.

\section{Conclusion and Recommendation}

Under an ever-changing business environment, more and more companies have adopted an open innovation business model to cut down costs and get better profitability. Innovation is no longer limited to an in-house $R \& D$ team. It can also be implemented from many different directions. Table 2 below summarizes the benefits from the adoption of open innovation strategy by the three popular coffee chain stores.

TABLE2 Partner Strategies Derived By The company through Open Innovation

\begin{tabular}{|c|c|c|c|c|c|}
\hline Name & Joint Venture & Franchise Agreement & Cross-Sector Alliance & Authorized Operation & Entrepreneurship \\
\hline Starbucks & $\bullet$ & $\bullet$ & $\bullet$ & $\bullet$ & \\
\hline $85^{\circ} \mathrm{C}$ & $\bullet$ & $\bullet$ & $\bullet$ & \\
\hline E Coffee & $\bullet$ & $\bullet$ & $\bullet$ & & \\
\hline
\end{tabular}

We can see from Table 2 above, that the three companies all have joint venture and cross-sector alliances. In addition, Starbucks employed a business strategy with various forms of cooperation under the open-innovation platform while retaining a major portion of its control power. On the other hand, $85^{\circ} \mathrm{C}$ Caféactively encourages internal startups, spurs employee morale, and grants franchises, which have all proved to be very successful. In addition, the subject companies all prefer using cross-sector alliances to create more addedvalue, such as setting up stores in school campuses, business buildings, hospitals, and other institutions. Therefore, the study concluded that enterprises should increasingly utilize more external resources for innovation and try to reduce costs for a win-win condition.

We recommend openinnovation business model forthe service industry in place oftraditional approaches. The timeless and boundary-less features of the Internet can also be used as an openinnovation business model to achieve greater benefit for the enterprises. The computer willundoubtedly offer more applications and advanced information searching tools. It will givethe enterprises more chances to offer differentiated services for distinctive customer clusters and give them a better quality of service.

\section{References}

[1] H. Chesbrough, Open Innovation: The New Imperative for Creating and Profiting from Technology. Boston: Harvard Business School Press, 2003.

[2] H. W. Pang, "Exploring Prospects and Problems with Open Innovation: A Case Study of Young Optics," Master's Thesis, College of Management, National Chiao Tung University, 2011.

[3] C. Y. Ku, "The Application of Open Innovation Theory in the Smart Phone Industry: A Case Study of the Qualcomm Reference Design," Master's Thesis, School of Management, National Taiwan University of Technology Science, 2013.

[4] Schumpeter, J A, The Theory of Economic Development. Cambridge: Harvard University Press, 1934.

[5] Y. Wang, M. Chou, and Z. Yuan, "Closed and Open Innovation: Basic Comparison and Case Analysis," Modern Economy Management Review, vol. 30, no. 11, pp. 1-42, 2008.

[6] Starbucks Coffee. http: //www.starbucks.com.tw/

[7] $85^{\circ} \mathrm{C}$. http: //www.85cafe.com/

[8] ECoffee. http: //www.ecoffee.com/ 